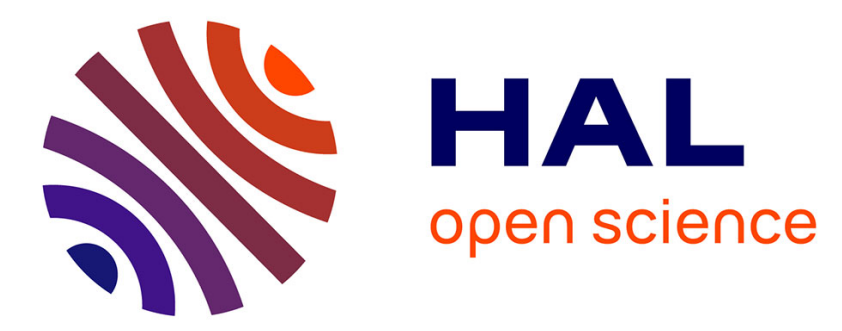

\title{
Hippocampal mu opioid receptors are modulated following cocaine self-administration in rat
}

David de Sa Nogueira, Romain Bourdy, Dominique Filliol, Pascal Romieu, Katia Befort

\section{- To cite this version:}

David de Sa Nogueira, Romain Bourdy, Dominique Filliol, Pascal Romieu, Katia Befort. Hippocampal $\mathrm{mu}$ opioid receptors are modulated following cocaine self-administration in rat. European Journal of Neuroscience, 2021, 53 (10), pp.3341-3349. 10.1111/ejn.15217 . hal-03359137

\section{HAL Id: hal-03359137 \\ https://hal.science/hal-03359137}

Submitted on 29 Sep 2021

HAL is a multi-disciplinary open access archive for the deposit and dissemination of scientific research documents, whether they are published or not. The documents may come from teaching and research institutions in France or abroad, or from public or private research centers.
L'archive ouverte pluridisciplinaire HAL, est destinée au dépôt et à la diffusion de documents scientifiques de niveau recherche, publiés ou non, émanant des établissements d'enseignement et de recherche français ou étrangers, des laboratoires publics ou privés. 
Hippocampal mu opioid receptors are modulated following cocaine self-administration in rat

David De Sa Nogueira, Romain Bourdy, Dominique Filliol, Pascal Romieu, Katia Befort*

\section{Running title: Cocaine regulation of mu opioid receptors}

Université de Strasbourg, Laboratoire de Neurosciences Cognitives et Adaptatives (LNCA UMR7364), Centre de la Recherche Nationale Scientifique, 12 rue Goethe, F-67000, Strasbourg France

Key words: mu opioid receptor, cocaine, hippocampus, gene expression, epigenetics

\section{Manuscript: 3583 words}

Abstract $=178$ words

\section{*Correspondence}

Katia Befort,

LNCA

Université de Strasbourg Faculté de Psychologie,

12 rue Goethe, F-67000

Strasbourg, France

E-mail: katia.befort@unistra.fr

\section{Abbreviations:}

Cocaine-SA: cocaine self-administration; DAMGO: [D-Ala2, N-MePhe4, Gly-ol]enkephalin ; DS: dorsal striatum ; HPC: hippocampus; LTP: long-term potentiation; MOP: Mu opioid receptor; PFC: prefrontal cortex; NAc: Nucleus Accumbens; VTA: ventral tegmental area. 


\begin{abstract}
Cocaine addiction is a complex pathology induced by long-term brain changes. Understanding the neurochemical changes underlying the reinforcing effects of this drug of abuse is critical for reducing the societal burden of drug addiction. The mu opioid receptor plays a major role in drug reward. This receptor is modulated by chronic cocaine treatment in specific brain structures, but few studies investigated neurochemical adaptations induced by voluntary cocaine intake. In this study, we investigated whether intravenous cocaine-self administration $(0.33 \mathrm{mg} / \mathrm{kg} /$ injection, FR1, 10 days $)$ in rats induces transcriptional and functional changes of the mu opioid receptor in reward related brain regions. Epigenetic processes with histone modifications were examined for two activating marks, H3K4Me3 and H3K27Ac. We found an increase of mu opioid receptor gene expression along with a potentiation of its functionality in hippocampus of cocaine self-administering animals compared to saline controls. Chromatin immunoprecipitation followed by qPCR revealed no modifications of the histone mark $\mathrm{H} 3 \mathrm{~K} 4 \mathrm{Me} 3$ and $\mathrm{H} 3 \mathrm{~K} 27 \mathrm{Ac}$ levels at mu opioid receptor promoter. Our study highlights the hippocampus as an important target to further investigate neuroadaptive processes leading to cocaine addiction.
\end{abstract}




\section{Introduction}

Addiction is a multi-factorial disease involving genetic, psychological and environmental factors, which has detrimental consequences for individuals and society. It is characterized by excessive intake over time, craving, continued drug use despite negative consequences and relapse (Koob \& Volkow, 2016). The progression of addiction is associated with neuroplastic changes (Robinson \& Kolb, 1999; Ron \& Jurd, 2005), whereby altered gene expression impacts neuronal function and behavior (Contet et al., 2004; Przewlocki, 2004; Rhodes \& Crabbe, 2005; McClung \& Nestler, 2008). In the case of cocaine these gene expression changes are widespread, but are particularly prominent in reward-related brain structures such as the prefrontal cortex (PFC) (Kalivas et al., 2005), dorsal striatum (DS) (Ahmed \& Kenny, 2011), hippocampus (HPC) (Zhou et al., 2014; Walker et al., 2018) and nucleus accumbens (NAc) (Russo et al., 2010). Many of these changes involve the opioid system, possibly linked with its role in reward and motivation (Le Merrer et al., 2009). Indeed, the mu opioid receptors (MOP) have been described as a gateway to addiction to several drugs, including cocaine (Contet et al, 2004; Charbogne et al, 2014).

Chronic cocaine induces molecular neuroadaptations of MOP in striatal regions, including increased MOP gene expression in both NAc (Azaryan et al., 1998; Leri et al., 2006) and DS (Valenza et al., 2016), MOP-agonist binding (Unterwald et al., 1992, 1994, 2001), and GTP $\gamma$ S binding (Schroeder et al., 2003). Noticeably, cocaine regulates gene expression through epigenetic processes, including histone modification, mostly in the NAc (Nestler, 2014; De Sa Nogueira et al., 2019). For example, cocaine increased the enrichment level of the trimethylated lysine 4 of histone 3 (H3K4Me3) in NAc following chronic administration which resulted in an enhancement of associated gene expression, such as FosB (Cates et al., 2019). Whether histone modifications could occur at MOP gene level following cocaine treatment is not yet known.

In this study, we investigated MOP gene expression and functionality following voluntary cocaine intake in rat, in brain reward regions (PFC, NAc, DS and HPC). To further characterize MOP transcript alterations in the HPC, we examined H3K4Me3 levels at MOP promoter region and also measured the enrichment of acetylated lysine 27 of histone 3 (H3K27Ac), a histone mark of active enhancers promoting gene expression (Achour et al., 2015). 


\section{Materials and Methods}

\section{Subjects}

Male Wistar rats ( $\mathrm{n}=34$, Janvier, France) weighting 250-300 $\mathrm{g}$ at the beginning of the experiments were habituated for two weeks to housing conditions in a temperature and humidity-controlled environment with a reverse $12 \mathrm{~h}$ light/dark cycle (lights on at 7:00 PM). Rats were grouped housed (5/cage) with ad libitum access to food and water until surgery and then single-housed. All experimental procedures were performed in agreement with the EU Directive 2010/63/EU for animal experiments and approved by the institutional ethics committee CREMEAS (Comité d'Éthique pour l'Expérimentation Animale de Strasbourg, France, APAFIS\#2015012716049550). All efforts were made to minimize animal suffering and to reduce the number of animals used.

\section{Drugs}

Cocaine hydrochloride was obtained from Cooper (\#1164500, Melun, France) and dissolved in sterile $\mathrm{NaCl}$ 0.9\%. The MOP agonist DAMGO was obtained from Sigma Aldrich (E7384, St Louis, USA).

\section{Surgery}

An intravenous catheterization procedure was performed as previously described (Fonteneau et al., 2017). Briefly, rats were anesthetized by i.p. injection (1 ml/kg) of a mixture containing $90 \mathrm{mg} / \mathrm{kg}$ of ketamine (Imalgene 1000®, Centravet, France) and $10 \mathrm{mg} / \mathrm{kg}$ of xylazine (Rompun ${ }^{\circledR}$, Centravet). Surgery was performed to implant a chronic indwelling catheter in the right jugular vein. Catheters were flushed daily with $150 \mu$ saline solution containing $100 \mathrm{U} / \mathrm{ml}$ heparin and $50 \mathrm{mg} / \mathrm{ml}$ ampicillin to prevent catheter clotting and potential infection, respectively.

\section{Cocaine self-administration procedure}

Seven days after surgery, drug self-administration was performed as previously described (Romieu et al., 2011; Fonteneau et al., 2017). Briefly, a computer driven syringe pump (Imetronic, Pessac, France) activated a $10 \mathrm{ml}$ syringe and pushed fluid into Silastic ${ }^{\circ}$ tubing connected to the rat through its externalized 23-gauge guide cannula. Each operant 
chamber was equipped with two $2.5 \mathrm{~cm}$-diameter holes on the same wall, $4 \mathrm{~cm}$ above the floor. Nose pokes into the inactive hole had no programmed consequence. Nose pokes into the active hole triggered the i.v. infusion of $60 \mu \mathrm{l}$ of cocaine hydrochloride $(0.33 \mathrm{mg} / \mathrm{kg}$, Cocaine-SA) or of the same volume of saline in control animals ( $\mathrm{NaCl} \mathrm{0.9 \% ,} \mathrm{Saline-SA),} \mathrm{which} \mathrm{were} \mathrm{ran}$ concurrently. The volume infused was adjusted according to the rat body weight every other session. A 40 s-time-out period began simultaneous to the cocaine infusion. A fixed-ratio 1 (FR1) paradigm was carried out for 10 days ( $2 \mathrm{~h}$ daily sessions). Animals were given an overdose of pentobarbital $(100 \mathrm{mg} / \mathrm{kg}$, i.v) $24 \mathrm{~h}$ after the last session followed by brain extraction to collect PFC, NAc, DS, and HPC (dorsal part).

\section{Quantitative real-time PCR}

Samples ( $\mathrm{n}=5-9 /$ group) were processed to extract total RNA using Ribozol (VWR, Fontenay-sous-bois, France) which was reverse transcribed $(750 \mathrm{ng})$ with iScript (iScript ${ }^{\mathrm{TM}}$ cDNA Synthesis Kit, Biorad, France). Real-time PCR was performed in triplicate (CFX96 Touch $^{\mathrm{TM}}$ apparatus, Biorad, France) in Sso Advanced ${ }^{\mathrm{TM}}$ Universal SYBR Green supermix (Biorad, France). Thermal cycling parameters were $30 \mathrm{sec}$ at $95^{\circ} \mathrm{C}$ followed by 40 amplification cycles of $5 \mathrm{sec}$ at $95^{\circ}$ and $45 \mathrm{sec}$ at $60^{\circ} \mathrm{C}$. Primer sequences were the following: MOP, ACAGCCTGTGCCCTCAGACC (forward) and CAGGAAGTTTCCGAAGAGGCC (reverse) and rplp0: CTGCCCGAGCCGGTGCCATC (forward) and TTCAATGGTACCTCTGGAG (reverse). Expression levels were normalized to rplpO housekeeping gene levels (Saad et al., 2019) and compared between Saline-SA and CocaineSA samples using the $2^{-\Delta \Delta} \mathrm{Ct}$ method (Livak \& Schmittgen, 2001).

\section{Agonist-stimulated $\left[{ }^{35} \mathrm{~S}\right]-\mathrm{GTP} \gamma \mathrm{S}$ binding assay}

The $\left[{ }^{35} \mathrm{~S}\right]$-GTP $\gamma \mathrm{S}$ binding assay was used to measure $\mathrm{G}$ protein activation following MOP receptor stimulation with DAMGO, as previously described (Scherrer et al., 2004). Membranes $(50 \mu \mathrm{g})$ were incubated in the assay buffer (50mM Tris-HCl pH 7.4; $3 \mathrm{mM} \mathrm{MgCl} 2$; $0.2 \mathrm{mM}$ EGTA; 100mM NaCl) containing 0.1nM [ $\left.{ }^{35} \mathrm{~S}\right]-\mathrm{GTP} \gamma \mathrm{S}$ (NEG030H, PerkinElmer, Courtaboeuf, France), $30 \mu \mathrm{M}$ GDP and DAMGO $\left(10^{-9} \mathrm{M}\right.$ to $\left.10^{-4} \mathrm{M}\right)$ for $1 \mathrm{~h}$ at $25{ }^{\circ} \mathrm{C}$. Radioactivity was detected using a Top-Count scintillation counter (PerkinElmer, Billerica, MA, USA). Basal $\left[{ }^{35} \mathrm{~S}\right]-\mathrm{GTP} \gamma \mathrm{S}$ binding was determined in the absence of agonist, and nonspecific binding by replacing $\left[{ }^{35} \mathrm{~S}\right]-\mathrm{GTP} \gamma \mathrm{S}$ by $10 \mu \mathrm{M}$ non-radiolabeled GTP $\gamma \mathrm{S}$. Stimulated specific binding was converted in percentage of basal specific binding, defined as $100 \%$. Data were analyzed using Prism 6 GraphPad software. Four to seven independent assays were 
performed in triplicate. Stimulation (\%), EC50s and IC50s were calculated for each experiment and averaged.

\section{Chromatin immunoprecipitation}

Samples were prepared as previously described (Caputi et al., 2014) with minor modifications. Frozen tissues were ground on carbonic ice before fixation (1\% formaldehyde) and quenched with glycine $(0.125 \mathrm{M})$. Tissue fragments were washed in presence of protease inhibitors (\#4693132001, Roche, France). Tissues were homogenized (0.5\% SDS, 10mM EDTA, 50mM Tris-HCL, pH8) and lysates were sheered using a diogenode bioruptor XL at $4^{\circ} \mathrm{C}$, to obtain DNA fragments <600 bp. Protein A magnetic beads (Dynabeads, Invitrogen) were coated $\left(4^{\circ} \mathrm{C}\right.$ overnight) with the respective antibody of interest (H3K4Me3, ab8580; H3K27Ac, ab4729, Abcam, France), washed and added to sheared chromatin for histone ChIPs $\left(4^{\circ} \mathrm{C}\right.$ overnight). A sample of each sheared chromatin (10\%) was used as input control. Samples were washed with RIPA buffer (HEPES-KOH 50mM pH7.5, LiCl 500mM, EDTA 1mM, NP$401 \%$, Na-Deoxycolate $0.7 \%$ ) and elution buffer (SDS 1\%, $\mathrm{NaHCO}_{3} 100 \mathrm{mM}$ ). Reverse crosslinking was performed at $65^{\circ} \mathrm{C}$ overnight, proteins and RNA removed with proteinase $\mathrm{K}$ and RNAse A (ThermoFisher, USA) respectively and DNA purified (Qiagen, France). A negative control without IgG was performed to test for nonspecific binding. PCR of MOP genomic sequence around the promoter region associated with the immunoprecipitated proteins was performed. Primers targeting MOP promoter region were the following: (forward) GGCCAGAGATGCATCGATCA and (reverse) GAGTCAGCCTGGCCAAGATT.

\section{Statistical analysis}

All results are expressed as mean \pm S.E.M. Behavioral data were analyzed using a repeated-measures two-way ANOVA followed by post-hoc Sidak tests when requested (GraphPad Prism V.7). Other data were analyzed using student t-test. Significance was set at $p$ $\leq .05$.

\section{Results}

\section{Acquisition of cocaine self-administration}


Rats were trained for 10 days during $2 \mathrm{~h}$ daily sessions of cocaine self-administration under the FR1 schedule of reinforcement (Figure 1A). The difference between cocaine and saline infusions was highly significant across all sessions [group effect, $\mathrm{F}(1,32)=76.78, p<$ .0001] (Figure 1A, top panel). The Anova analysis revealed a group effect $(\mathrm{F}(3,64)=17.92, p$ $<.0001]$. The animals receiving cocaine completed more than $80 \%$ of nose pokes in the active hole during the last 4 days (Figure 1A, lower panel), with the post-hoc analysis indicating a significant effect between cocaine-SA active versus cocaine-SA inactive for the last 4 sessions $(p<.0084)$. The mean number of cocaine infusions was $89 \pm 1.09$, while the mean number of

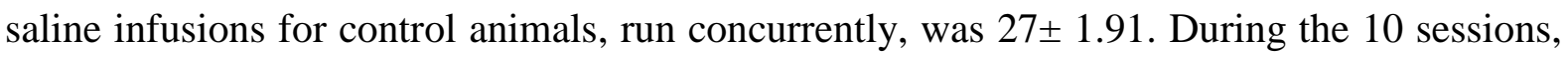
animals received a mean daily cocaine dose of $32.6 \pm 2.2 \mathrm{mg} / \mathrm{kg}$. Rats receiving saline did not differentiate between holes (50\% discrimination) and this discrimination is statistically significant between saline-SA and cocaine-SA $(\mathrm{F}(1,32)=21.73, p<.0001]$, starting on session (Sidack post-hoc test $p<.0044)$ (Figure 1B).

\section{Transcriptional changes of opioid receptors induced by cocaine self-administration}

We measured MOP gene expression in several brain-reward related structures. The analysis was performed $24 \mathrm{~h}$ after the last cocaine session in PFC, NAc, DS, and HPC, in order to explore mRNA expression in the absence of an acute effect of cocaine. We found that MOP gene expression was significantly decreased by cocaine-SA in DS [ $p=.03]$ and, in contrast, increased 1.85 fold in HPC [ $p=.045$ ] (Figure 2A). No significant changes could be detected in the PFC or NAc. The level of expression was not correlated with the amount of cocaine intake $\left(\mathrm{r}_{\mathrm{PFC}}=-.54 ; \mathrm{r}_{\mathrm{NAc}}=-.009 ; \mathrm{r}_{\mathrm{DS}}=.1 ; \mathrm{r}_{\mathrm{HPC}}=-.09\right)($ Figure 2B$)$.

\section{Cocaine self-administration modulated MOP functional activity}

To further characterize MOP receptor alterations, we investigated MOP functional activity by $\left[{ }^{35} \mathrm{~S}\right]-\mathrm{GTP} \gamma \mathrm{S}$ binding assay using MOP agonist DAMGO, in three brain regions of interest, PFC, DS and HPC. Not enough material was available from NAc samples to perform this experiment on single animals. Interestingly, a significant effect was observed in HPC, with an increased efficacy (Emax) in cocaine-SA rats compared to saline controls (Emax: Saline$\mathrm{SA}=148.7 \pm 3.4$; Cocaine-SA $=170 \pm 5.6 ; H P C: p=0.015)$ (Figure 3). The potency (EC50) was not altered in this region $\left(E C 50:\right.$ Saline-SA $=1,465.10^{-7} \mathrm{M} \pm 0.11$; Cocaine-SA $=1,863.10^{-}$ ${ }^{7} \mathrm{M} \pm 0.12$ ). No significant changes of either Emax or EC50 were observed in PFC and DS. 


\section{Histone modifications at MOP promoter region}

To further investigate MOP transcriptional changes in HPC, we examined whether epigenetic modifications occurred at MOP promoter region in this structure. We performed a chromatin-immunoprecipitation experiment followed by a qPCR (ChIP-qPCR) using specific primers directed towards MOP promoter. No enrichment was obtained in the absence of antibodies targeting the histone tails. In contrast, we obtained an enrichment of both marks at the MOP promoter, but the enrichment percentage compared to input in both conditions remained unchanged [H3K4Me3: $p=.165$ H3K27Ac: $p=.126]$, indicating no significant change in histone modification in HPC following cocaine intake (Figure 4).

\section{Discussion}

Role of hippocampal MOP in HPC following cocaine-SA. We investigated MOP transcript expression in several reward-related brain structures and observed, for the first time, a marked increase of MOP transcript in the HPC, a region essential for forming cocaine-context associations (Grant et al., 1996). Interestingly, this regulation was associated with increased functionality of the receptor in the same brain structure, as revealed by GTP $\gamma \mathrm{S}$ binding. Whether the observed gene up-regulation is specific to cocaine self-administration or would be observed with passive cocaine intake is not known. Also, we did not observe similar MOP gene regulation in the HPC following a binge sucrose (Smail-Crevier et al., 2018) paradigm (data not shown), suggesting that natural rewards may not modify MOP expression in this brain region. Moreover, there are scarce data on MOP gene alterations following drug-SA in HPC. An increase of MOP receptor (binding and GTP $\gamma \mathrm{S}$ studies) was observed in HPC following heroin-SA, with a low but constant drug intake during a short time (Fattore et al., 2007). Opposite results, with decreased MOP activity and efficiency, were reported following paradigms using high doses of heroin and escalating intake during a prolonged period (SimSelley et al., 2000; Maher et al., 2005). MOP hippocampal alteration was also reported following cannabinoid-SA with increased MOR binding and GTP $\gamma \mathrm{S}$ (Fattore et al., 2007). Also, MOP regulation may result from or lead to endogenous peptide regulations in HPC, which could directly impact neurochemical responses during cocaine intake (Jacobs et al., 2003). Altogether, this may reflect a key role for hippocampal MOP in associative learning related to drug administration. 
HPC is a crucial structure for the formation and maintenance of cocaine-context associations (Kilts et al., 2001; Wexler et al., 2001). In particular, the dorsal HPC controls context-induced reinstatement. Its inhibition (tetrodotoxin or muscimol) attenuated contextinduced, but not cue-induced reinstatement of cocaine seeking (Fuchs et al., 2005, 2007). A recent study showed that chemogenetic inhibition of dorsal, but not ventral hippocampal inputs to lateral septum specifically attenuated context-induced reinstatement of cocaine (McGlinchey \& Aston-Jones, 2018). Alterations in MOP gene expression may underlie cocaine-induced neuroplasticity in the brain. MOP knockout mice exhibited decreased cocaineSA (Mathon et al., 2005) and decreased cue-induced relapse associated with a decrease in HPC neuronal activity (Gutiérrez-Cuesta et al., 2014). Cocaine-SA induced long term potentiation (LTP) in CA1 region of the HPC has been reported after short withdrawal (Thompson et al., 2004). MOP activation is partly responsible for mossy fiber LTP in hippocampal CA3 (Derrick \& Martinez, 1994) and MOP deficient mice exhibited an impairment of spatial learning, that may be associated with LTP deficit observed in mossy fibers in CA3 of these mice (Jamot et al., 2003). Noteworthy, recent data indicate MOP expression in CA1 astrocytes and demonstrate astroglial MOP-mediated LTP in HPC (Nam et al., 2018, 2019). Altogether, even though little information is yet available, the behavioral and neurochemical data suggest that MOP is involved in cocaine responses by modifying the neuronal activity in this brain area closely related to memory processing.

MOP regulation in reward-related brain regions following cocaine-SA. In our conditions, no detectable modifications could be observed in the PFC or NAc of rats selfadministering cocaine. Reports investigating MOP regulations extensively focus on striatal regions with the vast majority relying on passive cocaine intake (for a review see Yoo et al., 2012). MOP up-regulations in the NAc were previously observed in passive paradigms (Unterwald et al., 1992, 1994; Izenwasser et al., 1996; Azaryan et al., 1998; Eipper-Mains et $a l ., 2013$ ) whereas no changes were observed in a voluntary paradigm (Valenza et al., 2016), similarly to our findings. This suggests that the cognitive processes involved in voluntary intake do not implicate MOP gene expression regulation in the NAc. A yoked control-operant group would assess whether the associative learning is specific to instrumental learning (Jacobs et al., 2003). No report in the literature was found for MOP regulation by cocaine in the PFC, and our results indicate no effect of cocaine-SA on MOP gene expression, suggesting a modest role for MOP in prefrontal functions. 
In contrast, we detected decreased MOP gene expression in the DS. This data is in contradiction with a previous work reporting a two-fold increase of MOP gene expression in Lewis strain with escalating cocaine-SA consumption and no change in Fischer strain showing a stable intake across sessions (Valenza et al., 2016). MOP binding was up-regulated in DS of cocaine users, a modification that lasted following long term abstinence (Zubieta et al., 1996), and MOP up-regulation was also observed in rat DS at mRNA (Unterwald et al., 1992, 1994, 2001) or functional level (Bailey et al., 2007; Schroeder et al., 2003) in passive chronic cocaine paradigms. Noticeably, few reports indicate the absence of MOP regulation in similar passive cocaine administration (Azaryan et al., 1996; Yuferov et al., 1999). Altogether, these results indicate that the rodent strain and/or the pattern of cocaine consumption represent specific factors that alter differentially the opioid system in DS.

Molecular mechanisms involved in cocaine induced regulation of MOP. Cocaine induced transcriptional changes can direct molecular, cellular and network features mediating behavioral responses. Interactions between G-protein coupled receptors or modulation of endogenous ligands acting at the coupling of these receptors may participate to the molecular mechanisms underlying cocaine responses. A recent mouse study highlighted a wider MOP/DOP neuronal co-expression following chronic morphine administration, and this coexpression was detected in novel brain areas located in circuits related to drug reward and emotional processing underlying withdrawal (Pierre et al., 2019). MOP/CB1 heteromers or differential intracellular signaling interactions were proposed as molecular mechanisms involved following heroin-SA or cannabinoid-SA, underlying differential regulation of MOP and CB1 in HPC (Fattore et al., 2007). We therefore hypothesize that similar adaptations could arise at MOP/DOP or MOP/CB1 levels following cocaine-SA in HPC. Further work will therefore investigate cellular and molecular consequences of cocaine-SA, and our preliminary results indicate an up-regulation of CB1 transcript in HPC following the same paradigm (DN, personal communication).

It is now well described that cocaine can induce epigenetic changes in the brain (Nestler, 2014; De Sa Nogueira et al., 2019). To investigate whether increased gene expression of MOP in HPC was under the control of such modifications, we analyzed H3K4me3 and H3K27ac activating marks at the level of MOP gene promotor. The absence of specific changes of $\mathrm{H} 3 \mathrm{~K} 4 \mathrm{me} 3$ and $\mathrm{H} 3 \mathrm{~K} 27 \mathrm{ac}$ levels in our conditions indicates that these marks were not associated with MOP gene regulation observed in the HPC. Previous work has shown H3K4Me3 regulation following cocaine intake in the HPC of postmortem cocaine abuser brains (Zhou et 
al., 2011), and this mark has been proposed as an opioid system element regulator in striatum (Caputi et al., 2014), indicating that the opioid system can be under the control of epigenetic regulations upon cocaine. Among other epigenetic changes, DNA methylation has been described at MOP promotor region in mouse brain and in heroin addict brain (Hwang et al., 2007, 2010; Nielsen et al., 2009, 2010; Chorbov et al., 2011). Whether DNA methylation occurs at the opioid system level upon cocaine-SA is not yet know. Further examination of the role of the opioid system in the HPC and associated epigenetic changes, will be crucial for the development of therapeutic treatments.

\section{Bibliography}

Achour, M., Le Gras, S., Keime, C., Parmentier, F., Lejeune, F.-X., Boutillier, A.-L., Neri, C., Davidson, I., \& Merienne, K. (2015) Neuronal identity genes regulated by superenhancers are preferentially down-regulated in the striatum of Huntington's disease mice. Hum. Mol. Genet., 24, 3481-3496.

Ahmed, S.H. \& Kenny, P.J. (2011) Cracking the Molecular Code of Cocaine Addiction. ILAR $J .$, 52, 309-320.

American Psychiatric Association (2013) Diagnostic and Statiscal Manual of Mental Disorders, Fifth Edition., Arlington, VA: American Psychiatric Association.

Azaryan, A. V, Clock, B.J., Rosenberger, J.G., \& Cox, B.M. (1998) Transient upregulation of $\mathrm{mu}$ opioid receptor mRNA levels in nucleus accumbens during chronic cocaine administration. Can. J. Physiol. Pharmacol., 76, 278-283.

Azaryan, A. V, Coughlin, L.J., Búzás, B., Clock, B.J., \& Cox, B.M. (1996) Effect of chronic cocaine treatment on mu- and delta-opioid receptor mRNA levels in dopaminergically innervated brain regions. J. Neurochem., 66, 443-448.

Bailey, A., Gianotti, R., Ho, A., \& Kreek, M.J. (2007) Downregulation of $\kappa$-opioid receptors in basolateral amygdala and septum of rats withdrawn for 14 days from an escalating dose "binge" cocaine administration paradigm. Synapse, 61, 820-826.

Caputi, F.F., Di Benedetto, M., Carretta, D., Bastias del Carmen Candia, S., D’Addario, C., Cavina, C., Candeletti, S., \& Romualdi, P. (2014) Dynorphin/KOP and nociceptin/NOP gene expression and epigenetic changes by cocaine in rat striatum and nucleus accumbens. Prog. Neuro-Psychopharmacology Biol. Psychiatry, 49, 36-46. 
Cates, H.M., Lardner, C.K., Bagot, R.C., Neve, R.L., \& Nestler, E.J. (2019) Fosb Induction in Nucleus Accumbens by Cocaine Is Regulated by E2F3a. eneuro, 6, ENEURO.032518.2019.

Chorbov, V.M., Todorov, A.A., Lynskey, M.T., \& Cicero, T.J. (2011) Elevated levels of DNA methylation at the OPRM1 promoter in blood and sperm from male opioid addicts. $J$. Opioid Manag., 7, 258-264.

Contet, C., Kieffer, B.L., \& Befort, K. (2004) Mu opioid receptor: a gateway to drug addiction. Curr. Opin. Neurobiol., 14, 370-378.

De Sa Nogueira, D., Merienne, K., \& Befort, K. (2019) Neuroepigenetics and addictive behaviors: Where do we stand? Neurosci. Biobehav. Rev., 106, 58-72.

Derrick, B.E. \& Martinez, J.L. (1994) Opioid receptor activation is one factor underlying the frequency dependence of mossy fiber LTP induction. J. Neurosci., 14, 4359-4367.

Eipper-Mains, J.E., Kiraly, D.D., Duff, M.O., Horowitz, M.J., McManus, C.J., Eipper, B.A., Graveley, B.R., \& Mains, R.E. (2013) Effects of cocaine and withdrawal on the mouse nucleus accumbens transcriptome. Genes. Brain. Behav., 12, 21-33.

Fattore, L., Viganò, D., Fadda, P., Rubino, T., Fratta, W., \& Parolaro, D. (2007) Bidirectional regulation of mu-opioid and $\mathrm{CB} 1$-cannabinoid receptor in rats self-administering heroin or WIN 55,212-2. Eur. J. Neurosci., 25, 2191-2200.

Fonteneau, M., Filliol, D., Anglard, P., Befort, K., Romieu, P., \& Zwiller, J. (2017) Inhibition of DNA methyltransferases regulates cocaine self-administration by rats: a genome-wide DNA methylation study. Genes, Brain Behav., 16, 313-327.

Fuchs, R.A., Eaddy, J.L., Su, Z.-I., \& Bell, G.H. (2007) Interactions of the basolateral amygdala with the dorsal hippocampus and dorsomedial prefrontal cortex regulate drug contextinduced reinstatement of cocaine-seeking in rats. Eur. J. Neurosci., 26, 487-498.

Fuchs, R.A., Evans, K.A., Ledford, C.C., Parker, M.P., Case, J.M., Mehta, R.H., \& See, R.E. (2005) The Role of the Dorsomedial Prefrontal Cortex, Basolateral Amygdala, and Dorsal Hippocampus in Contextual Reinstatement of Cocaine Seeking in Rats. Neuropsychopharmacology, 30, 296-309.

Grant, S., London, E.D., Newlin, D.B., Villemagne, V.L., Liu, X., Contoreggi, C., Phillips, 
R.L., Kimes, A.S., \& Margolin, A. (1996) Activation of memory circuits during cueelicited cocaine craving. Proc. Natl. Acad. Sci., 93, 12040-12045.

Gutiérrez-Cuesta, J., Burokas, A., Mancino, S., Kummer, S., Mart1'nmartı'n-Garc1á, E., \& Maldonado, R. (2014) Effects of Genetic Deletion of Endogenous Opioid System Components on the Reinstatement of Cocaine-Seeking Behavior in Mice. Neuropsychopharmacology, 39, 2974-2988.

Hwang, C.K., Kim, C.S., Kim, D.K., Law, P.-Y., Wei, L.-N., \& Loh, H.H. (2010) Upregulation of the mu-opioid receptor gene is mediated through chromatin remodeling and transcriptional factors in differentiated neuronal cells. Mol. Pharmacol., 78, 58-68.

Hwang, C.K., Song, K.Y., Kim, C.S., Choi, H.S., Guo, X.-H., Law, P.-Y., Wei, L.-N., \& Loh, H.H. (2007) Evidence of endogenous mu opioid receptor regulation by epigenetic control of the promoters. Mol. Cell. Biol., 27, 4720-4736.

Izenwasser, S., Heller, B., \& Cox, B.M. (1996) Continuous cocaine administration enhances $\mu$ - but not $\delta$-opioid receptor-mediated inhibition of adenylyl cyclase activity in nucleus accumbens. Eur. J. Pharmacol., 297, 187-191.

Jacobs, E.H., Smit, A.B., De Vries, T.J., \& Schoffelmeer, A.N.M. (2003) Neuroadaptive effects of active versus passive drug administration in addiction research. Trends Pharmacol. Sci.,.

Jamot, L., Matthes, H.W.D., Simonin, F., Kieffer, B.L., \& Roder, J.C. (2003) Differential involvement of the mu and kappa opioid receptors in spatial learning. Genes. Brain. Behav., 2, 80-92.

Kalivas, P.W., Volkow, N., \& Seamans, J. (2005) Unmanageable motivation in addiction: a pathology in prefrontal-accumbens glutamate transmission. Neuron, 45, 647-650.

Kilts, C.D., Schweitzer, J.B., Quinn, C.K., Gross, R.E., Faber, T.L., Muhammad, F., Ely, T.D., Hoffman, J.M., \& Drexler, K.P.G. (2001) Neural Activity Related to Drug Craving in Cocaine Addiction. Arch. Gen. Psychiatry, 58, 334.

Koob, G.F. \& Volkow, N.D. (2016) Neurobiology of addiction: a neurocircuitry analysis. The lancet. Psychiatry, 3, 760-773.

Lasseter, H.C., Xie, X., Ramirez, D.R., \& Fuchs, R.A. (2010) Sub-region specific contribution 
of the ventral hippocampus to drug context-induced reinstatement of cocaine-seeking behavior in rats. Neuroscience, 171, 830-839.

Le Merrer, J., Becker, J.A.J., Befort, K., \& Kieffer, B.L. (2009) Reward processing by the opioid system in the brain. Physiol. Rev., 89, 1379-1412.

Leri, F., Zhou, Y., Goddard, B., Cummins, E., \& Kreek, M.J. (2006) Effects of High-Dose Methadone Maintenance on Cocaine Place Conditioning, Cocaine Self-Administration, and Mu-Opioid Receptor mRNA Expression in the Rat Brain. Neuropsychopharmacology, 31, 1462-1474.

Livak, K.J. \& Schmittgen, T.D. (2001) Analysis of relative gene expression data using realtime quantitative PCR and. Methods, 25, 402-408.

Maher, C.E., Martin, T.J., \& Childers, S.R. (2005) Mechanisms of mu opioid receptor/Gprotein desensitization in brain by chronic heroin administration. Life Sci., 77, 1140-1154.

Mathon, D.S., Lesscher, H.M.B., Gerrits, M.A.F.M., Kamal, A., Pintar, J.E., Schuller, A.G.P., Spruijt, B.M., Burbach, J.P.H., Smidt, M.P., van Ree, J.M., \& Ramakers, G.M.J. (2005) Increased gabaergic input to ventral tegmental area dopaminergic neurons associated with decreased cocaine reinforcement in $\mu$-opioid receptor knockout mice. Neuroscience, $\mathbf{1 3 0}$, $359-367$.

McClung, C.A. \& Nestler, E.J. (2008) Neuroplasticity Mediated by Altered Gene Expression. Neuropsychopharmacology, 33, 3-17.

McGlinchey, E.M. \& Aston-Jones, G. (2018) Dorsal Hippocampus Drives Context-Induced Cocaine Seeking via Inputs to Lateral Septum. Neuropsychopharmacology, 43, 9871000.

Nam, M.-H., Han, K.-S., Lee, J., Bae, J.Y., An, H., Park, S., Oh, S.-J., Kim, E., Hwang, E., Bae, Y.C., \& Lee, C.J. (2018) Expression of $\mu$-Opioid Receptor in CA1 Hippocampal Astrocytes. Exp. Neurobiol., 27, 120.

Nam, M.-H., Han, K.-S., Lee, J., Won, W., Koh, W., Bae, J.Y., Woo, J., Kim, J., Kwong, E., Choi, T.-Y., Chun, H., Lee, S.E., Kim, S.-B., Park, K.D., Choi, S.-Y., Bae, Y.C., \& Lee, C.J. (2019) Activation of Astrocytic $\mu$-Opioid Receptor Causes Conditioned Place Preference. Cell Rep., 28, 1154-1166.e5. 
Nestler, E.J. (2014) Epigenetic mechanisms of drug addiction. Neuropharmacology, 76 Pt B, 259-268.

Nielsen, D.A., Hamon, S., Yuferov, V., Jackson, C., Ho, A., Ott, J., \& Kreek, M.J. (2010) Ethnic diversity of DNA methylation in the OPRM1 promoter region in lymphocytes of heroin addicts. Hum. Genet., 127, 639-649.

Nielsen, D.A., Yuferov, V., Hamon, S., Jackson, C., Ho, A., Ott, J., \& Kreek, M.J. (2009) Increased OPRM1 DNA methylation in lymphocytes of methadone-maintained former heroin addicts. Neuropsychopharmacology, 34, 867-873.

Pierre, F., Ugur, M., Faivre, F., Doridot, S., Veinante, P., \& Massotte, D. (2019) Morphinedependent and abstinent mice are characterized by a broader distribution of the neurons co-expressing mu and delta opioid receptors. Neuropharmacology, 152, 30-41.

Przewlocki, R. (2004) Opioid abuse and brain gene expression. Eur. J. Pharmacol., 500, 331349.

Rhodes, J.S. \& Crabbe, J.C. (2005) Gene expression induced by drugs of abuse. Curr. Opin. Pharmacol., 5, 26-33.

Robinson, T.E. \& Kolb, B. (1999) Alterations in the morphology of dendrites and dendritic spines in the nucleus accumbens and prefrontal cortex following repeated treatment with amphetamine or cocaine. Eur. J. Neurosci., 11, 1598-1604.

Rogers, J.L. \& See, R.E. (2007) Selective inactivation of the ventral hippocampus attenuates cue-induced and cocaine-primed reinstatement of drug-seeking in rats. Neurobiol. Learn. Mem., 87, 688-692.

Romieu, P., Deschatrettes, E., Host, L., Gobaille, S., Sandner, G., \& Zwiller, J. (2011) The inhibition of histone deacetylases reduces the reinstatement of cocaine-seeking behavior in rats. Curr. Neuropharmacol., 9, 21-25.

Ron, D. \& Jurd, R. (2005) The "Ups and Downs" of Signaling Cascades in Addiction. Sci. Signal., 2005, re14.

Russo, S.J., Dietz, D.M., Dumitriu, D., Morrison, J.H., Malenka, R.C., \& Nestler, E.J. (2010) The addicted synapse: mechanisms of synaptic and structural plasticity in nucleus accumbens. Trends Neurosci., 33, 267-276. 
Saad, L., Sartori, M., Pol Bodetto, S., Romieu, P., Kalsbeek, A., Zwiller, J., \& Anglard, P. (2019) Regulation of Brain DNA Methylation Factors and of the Orexinergic System by Cocaine and Food Self-Administration. Mol. Neurobiol., 56, 5315-5331.

Scherrer, G., Befort, K., Contet, C., Becker, J., Matifas, A., \& Kieffer, B.L. (2004) The delta agonists DPDPE and deltorphin II recruit predominantly mu receptors to produce thermal analgesia: a parallel study of mu, delta and combinatorial opioid receptor knockout mice. Eur. J. Neurosci., 19, 2239-2248.

Schroeder, J.A., Niculescu, M., \& Unterwald, E.M. (2003) Cocaine alters mu but not delta or kappa opioid receptor-stimulated in situ [35S]GTP?S binding in rat brain. Synapse, 47, $26-32$.

Sim-Selley, L.J., Selley, D.E., Vogt, L.J., Childers, S.R., \& Martin, T.J. (2000) Chronic heroin self-administration desensitizes $\mu$ opioid receptor- activated G-proteins in specific regions of rat brain. J. Neurosci., 20, 4555-4562.

Smail-Crevier, R.L., Maracle, A.C., Wash, S.I.J., Olmstead, M.C. (2018) Binge-like intake of sucrose reduces the rewarding value of sucrose in adult rats. Physiol Behav., 194, 420429.

Spanagel, R. \& Heilig, M. (2005) Addiction and its brain science. Addiction, 100, 1813-1822.

Thompson, A.., Swant, J., Gosnell, B.., \& Wagner, J.. (2004) Modulation of long-term potentiation in the rat hippocampus following cocaine self-administration. Neuroscience, 127, 177-185.

Unterwald, E.M., Horne-King, J., \& Kreek, M.J. (1992) Chronic cocaine alters brain mu opioid receptors. Brain Res., 584, 314-318.

Unterwald, E.M., Kreek, M.J., \& Cuntapay, M. (2001) The frequency of cocaine administration impacts cocaine-induced receptor alterations. Brain Res., 900, 103-109.

Unterwald, E.M., Rubenfeld, J.M., \& Kreek, M.J. (1994) Repeated cocaine administration upregulates kappa and mu, but not delta, opioid receptors. Neuroreport, 5, 1613-1616.

Valenza, M., Picetti, R., Yuferov, V., Butelman, E.R., \& Kreek, M.J. (2016) Strain and cocaine-induced differential opioid gene expression may predispose Lewis but not Fischer rats to escalate cocaine self-administration. Neuropharmacology, 105, 639-650. 
Walker, D.M., Cates, H.M., Loh, Y.-H.E., Purushothaman, I., Ramakrishnan, A., Cahill, K.M., Lardner, C.K., Godino, A., Kronman, H.G., Rabkin, J., Lorsch, Z.S., Mews, P., Doyle, M.A., Feng, J., Labonté, B., Koo, J.W., Bagot, R.C., Logan, R.W., Seney, M.L., Calipari, E.S., Shen, L., \& Nestler, E.J. (2018) Cocaine Self-administration Alters Transcriptomewide Responses in the Brain's Reward Circuitry. Biol. Psychiatry, 84, 867-880.

Wexler, B.E., Gottschalk, C.H., Fulbright, R.K., Prohovnik, I., Lacadie, C.M., Rounsaville, B.J., \& Gore, J.C. (2001) Functional Magnetic Resonance Imaging of Cocaine Craving. Am. J. Psychiatry, 158, 86-95.

Yoo, J.H., Kitchen, I., \& Bailey, A. (2012) The endogenous opioid system in cocaine addiction: what lessons have opioid peptide and receptor knockout mice taught us? Br. J. Pharmacol., 166, 1993-2014.

Yuferov, V., Zhou, Y., Spangler, R., Maggos, C.E., Ho, A., \& Kreek, M.J. (1999) Acute "binge" cocaine increases mu-opioid receptor mRNA levels in areas of the rat mesolimbic mesocortical dopamine system. Brain Res. Bull., 48, 109-112.

Zhou, Z., Enoch, M.-A., \& Goldman, D. (2014) Gene expression in the addicted brain. Int. Rev. Neurobiol., 116, 251-273.

Zhou, Z., Yuan, Q., Mash, D.C., \& Goldman, D. (2011) Substance-specific and shared transcription and epigenetic changes in the human hippocampus chronically exposed to cocaine and alcohol. Proc. Natl. Acad. Sci. U. S. A., 108, 6626-6631.

Zubieta, J.-K., Gorelick, D.A., Stauffer, R., Ravert, H.T., Dannals, R.F., \& Frost, J.J. (1996) Increased mu opioid receptor binding detected by PET in cocaine-dependent men is associated with cocaine craving. Nat. Med., 2, 1225-1229.

\section{Aknowledgements}

This work was supported by the Université de Strasbourg, the Centre National de la Recherche Scientifique (CNRS) and the Projet International de Coopération Scientifique (PICS) from the CNRS. DDSN was supported by a PhD fellowship from the Ministère de la Recherche and a $4^{\text {th }}$ year PhD funding from the Fonds Paul Mandel. We thank Dr Olmstead and Dr Massotte for discussions and critical reading of the manuscript.

\section{Author contributions}


$\mathrm{DN}$ and $\mathrm{KB}$ designed the experiments and wrote the manuscript; DN, RB, DF and PR performed the experiments, collected data and analyzed the results under the guidance of KB.

\section{Conflicts of Interest: None}

\section{Legends to figures}

Figure 1: Cocaine self-administration in rats. Rats followed a cocaine self-administration paradigm for 10 days (Cocaine-SA, 2h/d) with each infusion delivering $0.33 \mathrm{mg} / \mathrm{kg}$ of cocaine, or saline for the control animals (Saline-SA). A. The number of infusions (top panel) and the number of nose-pokes (lower panel) are presented across all sessions. B. The percentage of discrimination of the active hole versus the inactive hole is depicted. The difference between cocaine and saline infusions was highly significant across all sessions. ANOVA repeated measures (group effect): $* * * p<.0001$. Curves represent the mean \pm SEM $(\mathrm{n}=17$ /group).

\section{Figure 2: Mu opioid receptor gene expression following cocaine self-}

administration. A. Brain samples were processed for qPCR, and normalization of data was performed using rplp0 as a reference gene (see Methods). MOP gene expression is increased in the HPC and decreased in the DS following cocaine-SA. Its expression remained unchanged in the PFC and NAc. Student t-test: ${ }^{*} p<.05$ vs control. Histograms represent the mean + S.E.M n= 5-10/group. Samples were dissected with large (3 mm) or small $(1.9 \mathrm{~mm})$ punchers as indicated on slices, with distance in $\mathrm{mm}$ from Bregma. B. Correlation plots between cocaine intake and gene expression. Lines represent the regression curve for each region.

Figure 3: Mu opioid receptor activity following cocaine self-administration. Membrane were prepared from PFC, DS and HPC and processed for $\left[{ }^{35} \mathrm{~S}\right]-\mathrm{GTP} \gamma \mathrm{S}$ binding experiment using DAMGO, a MOP receptor agonist, to activate the receptor (see Methods). Curves represent MOP activation by increasing concentrations of DAMGO in saline control and cocaine self-administration samples (Saline-SA, $n=4-6$ and Cocaine-SA, $n=4-7$ ). Maximum activation (Emax) was increased in HPC and remained unchanged in PFC and DS. Mean + S.E.M. Student t-test: ${ }^{*} p<.05$ vs control. 
Figure 4: Histone modifications at the MOP promoter following cocaine selfadministration. Chromatin was extracted from HPC samples, immunoprecipitated with antibodies recognizing $\mathrm{H} 3 \mathrm{~K} 4 \mathrm{Me} 3$ or H3K27Ac, two activating histones marks. Samples were further processed for qPCR using specific primers targeting the MOP promoter. Results were normalized according to the input (see Methods). The enrichment of histone marks at MOP promoter region was not modulated by cocaine self-administration. Enrichment was specific to both antibodies as no enrichment could be detected without antibody. Histograms represent the mean + S.E.M. $n=5-7 /$ group for Saline-SA and Cocaine-SA groups. 